\title{
Removal of Trimethoprim from Water using Carbonized Wood Waste as Adsorbents
}

\author{
S. A. Adesokan ${ }^{\mathrm{a}}$, A. A. Giwa ${ }^{\mathrm{a}, *}$, I. A. Bello \\ ${ }^{a}$ Department of Pure and Applied Chemistry, Ladoke Akintola University of Technology, Ogbomoso
}

\begin{abstract}
Daniellia-oliveri sawdust-based adsorbents were employed to remove trimethoprim (TMP) from water. The sawdust was thermally carbonized and activated in-stu with $\mathrm{ZnCl} 2$ and $\mathrm{H}_{3} \mathrm{PO}_{4}$ separately. The adsorbents surface features were profiled using scanning electron microscopic (SEM) and $\mathrm{pH}$ point of zero charge $\left(\mathrm{pH}_{p z c}\right)$ analyses. The prospects of the adsorbents for the removal of trimethoprim from water were verified. The adsorption processes were performed under different experimental conditions. The adsorption isotherm, the kinetics, and the thermodynamics were studied; and the data fitting output revealed that both chemisorptions and physisorption occurred. Surface and pore diffusion played active role in the adsorption of TMP by the adsorbents. The optimum conditions for adsorption of TMP by the adsorbents were pH at slightly acidic to neutral medium and temperature at room temperature. The fitting isotherm models were: Langmuir $\left(R^{2}=0.993\right)$ for the zinc-chloride-activatedcarbon, Temkin $\left(R^{2}=0.962\right)$ for the phosphoric-acid-activated-carbon, and the kinetics: pseudo-second order $\left(R^{2}=0.997\right)$ for both. The maximum monolayer adsorption capacities of the adsorbents for TMP was 4.115 and $6.495 \mathrm{mg} / \mathrm{g}$, respectively. The thermodynamic parameters determined suggested feasibility, spontaneity, and endothermicity of the adsorption processes. The results reveal that the adsorbents were good prospects for the removal of TMP from water.
\end{abstract}

DOI: $10.46481 /$ jnsps. 2021.320

Keywords: Carbonization, Activation, Adsorption, Daniellia-oliveri sawdust, Activated Carbon, Trimethoprim.

Article History :

Received: 28 July 2021

Received in revised form: 15 September 2021

Accepted for publication: 16 September 2021

Published: 29 November 2021

(C)2021 Journal of the Nigerian Society of Physical Sciences. All rights reserved. Communicated by: E. Etim

\section{Introduction}

Necessities for procurement of means of livelihood, maintenance of quality life and attainment of luxurious status had prompted man to recreate the environment. Advancements in various frontiers of human endeavors had created lots of pollutants and contaminants.

Sources of pollutants and contaminants in the environment include: agricultural practices, medicine/pharmaceutical indus-

${ }^{*}$ Corresponding author tel. no: +2348035065456

Email address: giwa1010@gmail.com (A. A. Giwa) tries, automobile/mechanical works, transportation, construction, manufacturing, tourism, research, productions and so on [1]. The propensity of these hazardous substances into the lithosphere and hydrosphere was high as a result of their proximity to man. Most of these anthropogenic toxic materials upset the delicate balance of the ecosystem. The resultant of this upsetting was untoward environmental episodes.

The advancement of man in various facets has led to new products, generation of new by-products and new wastes. Some of new wastes had been identified as emerging contaminants of concerns (ECCs). The ECCs were of different categories: 
nano-materials [1] pesticides, herbicides, personal care products and pharmaceuticals (PCPPs) [2]. The pharmaceuticals are designed to fight specific ailment and/or microorganisms that cause diseases. When administered through involuntary exposure, the pharmaceuticals had been appraised to induce an array of health and ecological complications [3]. Some of the identified ecological complications include and not limited to: hermaphroditic feature in fish; regeneration impairment in injured toads; and drug resistance in microbe populations $[4,5$, 6]. The environmental levels of pharmaceuticals are generally low to cause acute health effect on human. However considering chronic exposure, precautionary principle approach should be adopted to forestall incidence of health complications. The involuntary presence of pharmaceuticals should be prevented in public resources like drinking water and air to protect the vulnerable groups like children and populations with compromised immune system from involuntary exposure.

Pharmaceuticals were of different categories classified by their functions. One of the main categories with high dispensability was antibiotics e.g. trimethoprim (TMP) [7, 8, 9]. High dispensability of antibiotics was responsible for their high levels in the environment. Presence of antibiotics in the environment was highly undesirable as they induce drug resistance in microorganisms and this is a major factor of pandemic [10,11]. TMP is an antibacterial and anti-malarial drug. It has reported half-lives in the range 5 - 100 days. It is insignificantly photodegraded, which suggests a relative persistence [12] in the environment. TMP is mutagenic, teratogenic, embryotoxic and folate antagonism [13]. Hence TMP should be removed from water resources.

The researchers are working to develop technologies [14] and strategies $[15,16,17,18]$ to remove various forms of pollutants and contaminants, including pharmaceuticals from water. Recently the most sustainable technology so far developed was adsorption process [19, 20, 21, 22, 23, 24, 25]. The trending strategy was the use of agro-wastes as adsorbents for the removal of pollutants and contaminants. In Nigeria, wood waste like sawdust remains one of the high volumes, posing great challenge to manage. In 2010, Nigeria generated over $1,000,000 \mathrm{~m}^{3}(353,146.667$ tonnes) [26] of sawdust and most managed by open air combustion. This combustion method led to generation of COx, NOx, SOx: radiation forcing substances [26]. Conversion of the sawdust to highly demanded product like adsorbent is both economically and environmentally sustainable strategy.

In this work, Daniellia-oliveri sawdust, a high volume agroprocessing waste in Nigeria and not yet reported for any usage, was processed and used to remove from contaminated water.

\section{Materials and Methods}

\subsection{Materials}

Some of the materials used include Daniellia-oliveri sawdust (collected from a local factory, washed, dried and segre- gated), analytical grade $\mathrm{ZnCl}_{2}, \mathrm{H}_{3} \mathrm{PO}_{4}$, (purchased from local chemical dealer) TMP (primary standard, $>98.5 \%$ purity) (supplied Bond Chemical Industries Limited, Awe, Oyo) and $\mathrm{HCl}$. The equipment made used of were furnace (Carbolite AAF 1100), ultraviolet-visible (UV) (B-UV 1800PC) spectrophotometer, $\mathrm{pH}$ meter (Jenway 3520), and scanning electron microscope (SEM) (Aspex 3020) and oven (Carbolite).

\section{2. $T M P$}

The structural formula and the properties of trimethoprim are given in Figure 1 [27] and Table 1 [28] below.

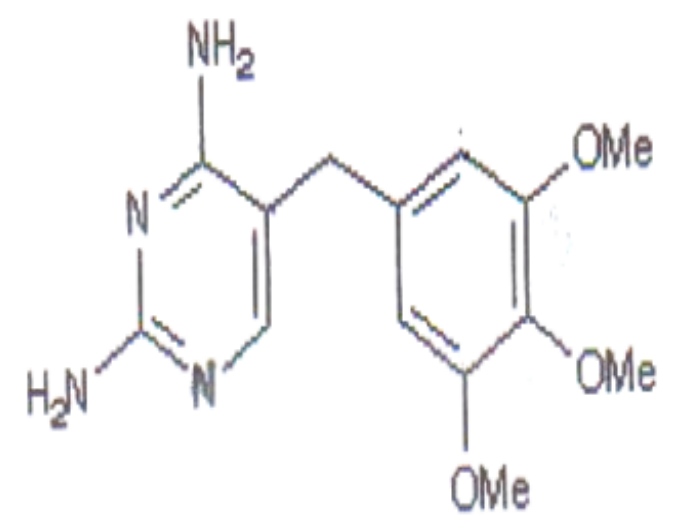

Figure 1: Trimethoprim

\subsection{Preparation of Adsorbents}

The Daniellia-oliveri sawdust was washed with plenty of distilled water to remove surface impurities and then sundry. The sample was dried in an oven at $70{ }^{\circ} \mathrm{C}$ for 72 hours; then ground and stored as Raw Daniellia Sawdust (RDS). The method was described elsewhere [29], 3g of RDS was mixed with 3 $\mathrm{mL}$ of $1 \mathrm{M} \mathrm{H}_{3} \mathrm{PO}_{4}$ and $3 \mathrm{~mL}$ of $1 \mathrm{M} \mathrm{ZnCl}_{2}$ each in separate crucibles. These were subjected to the furnace at $800{ }^{\circ} \mathrm{C}$ (carbonization and activation in self-generated atmosphere) for 5 minutes. The adsorbents were stored in air tight container as $\mathrm{H}_{3} \mathrm{PO}_{4}$ activated carbon (PACB) and $\mathrm{ZnCl}_{2}$ activated carbon (ZAC) respectively.

\subsection{Characterization of Adsorbents}

SEM and $\mathrm{pH}_{p z c}$ analyses were carried out using methods [30] and [31] respectively to study the surface morphology and $\mathrm{pH}$ of point of zero charge of the adsorbents.

\subsection{Batch Adsorption Studies}

The triplicate optimized batch adsorption processes were carried out. The adsorption bottles containing adsorbent-adsorbate mixtures were shake on a mechanical shaker operating at 160 rpm. The effects of contact times ( $0-240 \mathrm{~min})$, adsorbent dosages $(0.05-0.5 \mathrm{~g})$, pHs $(2,5,8)$, initial adsorbate concentrations $(15-50 \mathrm{mg} / \mathrm{L})$, and temperatures $\left(29-60^{\circ} \mathrm{C}\right)$ were determined. After the processes reached equilibrium, the mixtures were filtered using filter papers and the filtrates analyzed at 282 
Table 1: Properties of Trimethoprim

\begin{tabular}{cc}
\hline Common Names: & Trimethoprim, Trimethoprime, trimethoprimum, trimetoprima, trimpex \\
IUPAC Names & $5-[(3,45$-trimethoxyphenyl)methyl $]-2,4-$ pyrimidinediamine \\
Molecular formula & $C_{14} H_{18} N_{4} O_{3}$ \\
Molecular weight & $290.32 \mathrm{~g} / \mathrm{mol}$ \\
UN Number & 2811 \\
Max $\lambda$ & $282 \mathrm{~nm}$ \\
Solubility & $400 \mathrm{mg} / \mathrm{L}\left(25^{\circ} \mathrm{C}\right)$ \\
Toxicity & Vomiting, headache, mental depression, confusion, bone marrow depression \\
pKa & 7.12 \\
Description & Antibacterial, antimalaria \\
Interaction sites & $\pi-\pi, n-\pi,-\mathrm{NH}_{2}, \equiv \mathrm{N}:$ \\
\hline
\end{tabular}

nm with the UV spectrometer to determine the absorbances of trimethoprim in solutions after adsorption. The absorbances were converted to corresponding concentrations using standard curve equation. Each experiment was performed in triplicate. Equations (1) and (2) were used to determine amount of adsorbate adsorbed per unit mass of adsorbent and percentage adsorbate removal respectively:

$$
\begin{aligned}
& q_{e}=\frac{\left(C_{i}-C_{e}\right) V}{m} \\
& \% \text { adsorbate removal }=\frac{\left(C_{i}-C_{e}\right) V}{C_{i}} \times 100
\end{aligned}
$$

where $q_{e}, C_{i}, C_{e}, m$ and $V$ are the amount of trimethoprim adsorbed by the adsorbent at equilibrium $(\mathrm{mg} / \mathrm{g})$; the initial trimethoprim concentration $(\mathrm{mg} / \mathrm{L})$; the trimethoprim concentration at equilibrium $(\mathrm{mg} / \mathrm{L})$; the mass of the adsorbent $(\mathrm{g})$; and the volume of the solution (L) respectively.

\subsection{Adsorption Isotherms}

Table 2 contains selected isotherm models used to process experimental data and then described the adsorption processes.

The Langmuir Model: A plot of $\mathrm{C}_{e} / \mathrm{q}_{e}$ versus $\mathrm{C}_{e}$ gives a straight line with intercept: $1 / K \cdot q_{0}$; and slope: $1 / q_{0}$. Langmuir isotherm equilibrium parameter, $\mathrm{R}_{L}: R_{L}=\frac{1}{1+K_{L} C_{i}}$ [39]. $\mathrm{C}_{i}=$ highest initial adsorbate concentration $(\mathrm{mg} / \mathrm{L}) ; \mathrm{R}_{L}>1=$ unfavourable; $R_{L}=1=$ linear; favorable $0<\mathrm{R}_{L}<1=$ favourable and $\mathrm{R}_{L}=0=$ irreversible. The Freundlich Model: A log-log plot should yield an intercept of $\log \mathrm{K}_{F}$ and a slope of $1 / \mathrm{n}$. $\mathrm{n}$ defines isotherm shape; $1 / \mathrm{n}=0=$ irreversible; $(0<1 / \mathrm{n}<1)=$ favourable; unfavourable $(1 / \mathrm{n}>1) ; \mathrm{n}=1$ =linear; $\mathrm{n}>1=$ physical process and $\mathrm{n}<1=$ chemical process. The Temkin Model: $\mathrm{K}_{T}$ $=$ Temkin isotherm equilibrium binding constant $(\mathrm{L} / \mathrm{g}) ; \mathrm{b}_{T}=$

\begin{tabular}{|c|c|c|}
\hline Model & Linearised Formulae & Reference \\
\hline Harkin-Jura & $\begin{array}{l}\ln q_{e}=\frac{1}{n} \ln K-\frac{1}{n} \ln C_{e} \\
\frac{1}{q^{2}}=\frac{B}{A}-\frac{1}{A} \log C_{e} \\
\frac{C_{e}}{q_{e}}=\frac{1}{K \cdot q_{0}}+\frac{C_{e}}{q_{0}}\end{array}$ & {$[32]$} \\
\hline & & [34] \\
\hline Langmuir & & \\
\hline Freundlich & $\ln q_{e}=\ln K_{F}+\frac{1}{n} \ln C_{e}$ & [35] \\
\hline Temkin & $q_{e}=B \ln K_{T}+B \ln C_{e}$ & [36] \\
\hline Redlich-Peterson & $\begin{array}{l}\log \frac{C_{e}}{q_{e}}=\log K_{R}+ \\
\beta_{R} T \log C_{e}\end{array}$ & [37] \\
\hline $\begin{array}{l}\text { Dubinin- } \\
\text { Radushkevich }\end{array}$ & $\ln q_{e}=\ln \left(q_{s}\right)-\left(K_{a d} \varepsilon^{2}\right)$ & [38] \\
\hline
\end{tabular}

Table 2: Isotherm Equations

Temkin isotherm constant; $\mathrm{R}=$ universal gas constant $(8.314$ $\mathrm{J} / \mathrm{mol} / \mathrm{K}) ; \mathrm{T}=$ Temperature at $298 \mathrm{~K} ; \mathrm{B}=$ Constant related to heat of sorption $(\mathrm{J} / \mathrm{mol})$. The Redlich-Peterson isotherm: $\mathrm{C}_{e}=$ equilibrium concentration; $\mathrm{q}_{e}=$ adsorption capacity of the adsorbent; $\beta=$ desorption constant and $\mathrm{K}_{R}=\mathrm{R}-\mathrm{P}$ isotherm constant $(\mathrm{g} / \mathrm{L})$. The Dubinin-Radushkevich Model: $\varepsilon=R T \ln \left[1+\frac{1}{C_{e}}\right]$; $E=\left[\frac{1}{\sqrt{2} B_{D R}}\right] ; \mathrm{K}_{a d}=\mathrm{B}_{D R} ; \mathrm{E}<8 \mathrm{~kJ} / \mathrm{mol}$ (physical adsorption); $\mathrm{E}$ $=20-40 \mathrm{~kJ} / \mathrm{mol}$ (chemical adsorption) [38]; $\mathrm{E}=8-16 \mathrm{~kJ} / \mathrm{mol}$ (ion-exchange) [40]; $\mathrm{q}_{e}=$ amount of adsorbate on the adsorbent at equilibrium $(\mathrm{mg} / \mathrm{g}) ; \mathrm{q}_{s}=$ theoretical isotherm saturation capacity $(\mathrm{mg} / \mathrm{g}) ; \mathrm{K}_{a d}=$ Dubinin-Radushkevich isotherm constant $\left(\mathrm{mol}^{2} / \mathrm{kJ}^{2}\right)$. 


\subsection{The Kinetics}

Samples were taken from adsorption bottles at time intervals and the amounts of adsorbates were measured. The amount of adsorbed adsorbate at time $t, q_{t}(\mathrm{mg} / \mathrm{g})$, was calculated using Equation 3 and kinetic parameters were calculated using kinetic equations presented in Table 3.

$$
q_{t}=\frac{\left(C_{0}-C_{t}\right) V}{m}
$$

The Pseudo-First Order: $q_{e}$ and $q_{t}$ are the amounts of the dye adsorbed $(\mathrm{mg} / \mathrm{g})$ at equilibrium and at time $\mathrm{t}(\mathrm{min})$, respectively, and $k_{1}$ is the rate constant adsorption $\left(\mathrm{min}^{-1}\right)$. A plot of $\log \left(q_{e}-q_{t}\right)$ versus $t$ gives a slope of $\left(-\frac{k_{1}}{2.303}\right)$ and intercept of $\log q_{e}$. The Pseudo-Second Order: $h=k_{2} \cdot q_{e}^{2} ; q_{e}$ is the amount of the solute adsorbed at equilibrium per unit mass of adsorbent $(\mathrm{mg} / \mathrm{g}), q_{t}$ is the amount of solute adsorbed $(\mathrm{mg} / \mathrm{g})$ at any given time, $t(\mathrm{~min})$ and $k_{2}$ is the rate constant for pseudosecond-order adsorption $(\mathrm{g} / \mathrm{mg} / \mathrm{min})$ and $h$, known as the initial sorption rate. The values of $q_{e}$ and $\mathrm{k}_{2}$ can be obtained from the slope and intercept of the plot of $t / q_{t}$ versus $t$ respectively. If the sorption follows pseudo-second order, $h$, is described as the initial rate constant as $t$ approaches zero. The Elovich: $\alpha$ is the initial adsorption rate $(\mathrm{mg} / \mathrm{g}$. $\mathrm{min}), \beta$ is the desorption constant $(\mathrm{g} / \mathrm{mg})$ and $\mathrm{q}_{t}$ is the amount of solute adsorbed $(\mathrm{mg} / \mathrm{g})$ at any given time, $\mathrm{t}(\mathrm{min})$. A plot of $q_{t}$ versus $\ln t$ gives a straight line with intercept $\frac{1}{\beta} \ln (\alpha \beta)$ and slope $\left(\frac{1}{\beta}\right)$. Intra-Particle Diffusion: $\mathrm{q}_{t}(\mathrm{mg} / \mathrm{g})=$ quantity of adsorbate adsorbed at time, $\mathrm{t}$ and $\mathrm{k}_{\text {id }}\left(\mathrm{mg} / \mathrm{gh}^{0.5}\right)=$ intra-particle diffusion constant. A graph of $\mathrm{q}_{t}$ versus $\mathrm{t}^{0.5}$ gives a straight line with slope, $\mathrm{k}_{i d}$, and intercept, $\mathrm{x} . \mathrm{x}$ defines the thickness of the boundary layer. The Boyd Kinetic: $\mathrm{B}=\frac{\pi^{2} D_{i}}{r^{2}} ; \mathrm{B}$ is a constant; $\mathrm{D}_{i}\left(\mathrm{~m}^{2} / \mathrm{s}\right)$ is diffusion coefficient; $r$ is radius of adsorbent particle; $F$ is the fraction of adsorbate adsorbed at given time, $t$, and $\mathrm{Bt}$ is a function of $F$. If graph of $[-0.4977-\ln (1-F)]$ vs time, $t$, is linear and intercept $=$ 0 , then the determining step of the adsorption process is intraparticle diffusion; but if intercept $\neq 0$, the determining step may be film diffusion.

\subsection{Thermodynamic Study}

Experiments were performed at $29,40,50,60$ and $70{ }^{\circ} \mathrm{C}$ to establish the effect of temperature on the adsorption capacities of ZAC and PACB for the trimethoprim. The thermodynamic

Table 3: Kinetic Equations

\begin{tabular}{lll}
\hline Kinetic & Equation & Reference \\
\hline Pseudo-First & $\log \left(q_{e}-q_{t}\right)=\log q_{e}-\frac{k_{1}}{2.303} \cdot t$ & {$[41]$} \\
Order & $\frac{t}{q_{t}}=\frac{1}{h}+\frac{t}{q_{e}}$ & {$[42]$} \\
$\begin{array}{l}\text { Pseudo- } \\
\text { Second Order }\end{array}$ & \\
Elovich & $q_{t}=\frac{1}{\beta} \ln (\alpha \beta)+\left(\frac{1}{\beta}\right) \ln t$ & {$[43$,} \\
& & $44]$ \\
Intra-Particle & $q_{t}=k_{i d} t^{0.5}+x$ & {$[45]$} \\
Diffusion & & \\
Boyd & $-0.4977-\ln (1-\mathrm{F})=\mathrm{Bt}$ & {$[46]$} \\
\hline
\end{tabular}

parameters of the adsorption were determined using the equations (4) and (5).

$$
\begin{aligned}
& \Delta G^{0}=-2.303 R T \log K \\
& \log \left(\frac{C_{A e}}{C_{e}}\right)=\frac{\Delta S^{0}}{2.303 R}-\frac{\Delta H^{0}}{2.303 R T}
\end{aligned}
$$

$\mathrm{K}=\left(\frac{C_{A e}}{C_{e}}\right) ; \mathrm{C}_{A e}=\left(C_{i}-C_{e}\right)(\mathrm{mg} / \mathrm{L})=$ amount of trimethoprim adsorbed on adsorbent at equilibrium; $\mathrm{C}_{e}(\mathrm{mg} / \mathrm{L})=$ amount of trimethoprim in solution at equilibrium; $\mathrm{R}=$ gas constant $(8.314 \mathrm{~J} / \mathrm{mol} / \mathrm{K}) ; \mathrm{T}=$ temperature $(\mathrm{K})$. The enthalpy change $(\Delta \mathrm{H})$, the entropy change $(\Delta \mathrm{H})$ and change in satndard free energy $(\Delta \mathrm{G})$ were calculated. The spontaneity of the processes was thereby determined.

\section{Results and Discussion}

\subsection{Morphology of ZAC and PACB}

Figure 2 showed characteristic surface morphology of the adsorbents. Carbonization and activation processes impacted the adsorbents' surfaces with characteristic morphology and chemical profile. Using Gwyddion 2.23-1 application for SEM image processing, the average pore diameters respectively of ZAC and PACB were approximately 30 and $55 \mathrm{~nm}$. High temperature of carbonization removed volatile compounds in the matrix of raw sawdust thereby created pores. High temperature could also break down cellulosic contents of the precursor sawdust and aided aromatization of carbon chains. High temperature chemical activation effected dehydration and decarboxylation of sawdust. It could be deduced from the changes in the surface morphology after adsorption that pores were active in adsorbing trimethoprim molecules.

\subsection{Determination of Equilibrium Time and Effect of Contact Time on Trimethoprim Adsorption}

The amount of TMP adsorbed per unit mass $(q)$ of each of ZAC and PACB increased rapidly within first $40 \mathrm{~min}$. The $q$ thereafter increased slowly and insignificantly over next two hours for both systems. After $60 \mathrm{~min}$, almost all the available adsorption sites had been occupied for both systems. The $q$ at time $t\left(\mathrm{q}_{t}\right)$ for the TMP-ZAC system was $1.123 \mathrm{mg} / \mathrm{g}$ within first $60 \mathrm{~min}$ while it was $0.272 \mathrm{mg} / \mathrm{g}$ for the $180 \mathrm{~min}$ afterwards. The $\mathrm{q}_{e}$ for the TMP-PACB system was $0.996 \mathrm{mg} / \mathrm{g}$ in first 60 min while $0.204 \mathrm{mg} / \mathrm{g}$ for the $180 \mathrm{~min}$ afterwards (Figure 3a). These increments for the next $180 \mathrm{~min}$ after first $60 \mathrm{~min}$ were economically insignificant. The economic time of adsorption for both systems was $60 \mathrm{~min}$.

\subsection{Effect of Adsorbent Dose on Trimethiprim (TMP) Adsorp- tion}

The increase in mass of each of ZAC and PACB led to decreased amount of TMP adsorbed per unit mass during adsorption processes. The increased mass of the adsorbents provided more sites of adsorption for constant amount of TMP molecules. ZAC and PACB adsorbed equal amounts of the 


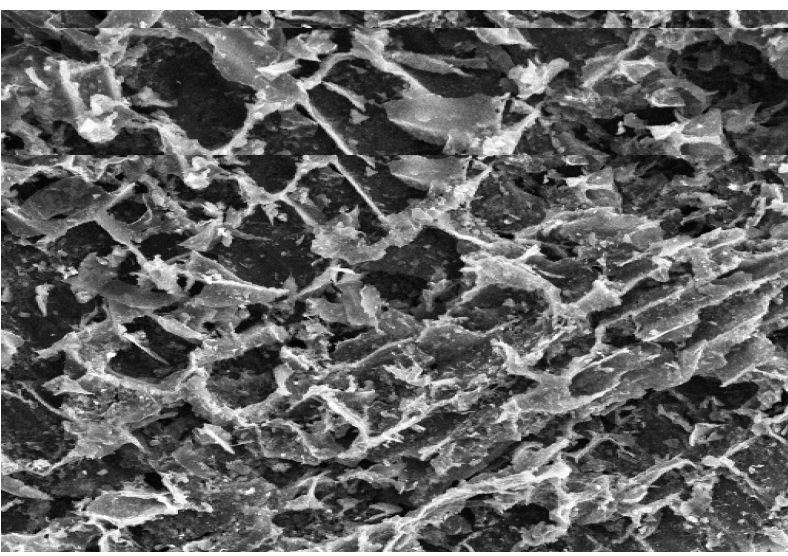

(a)

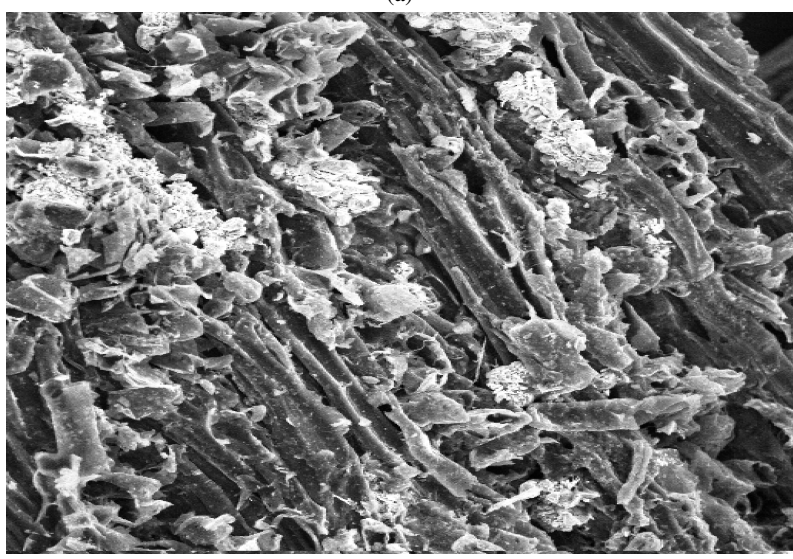

(c)

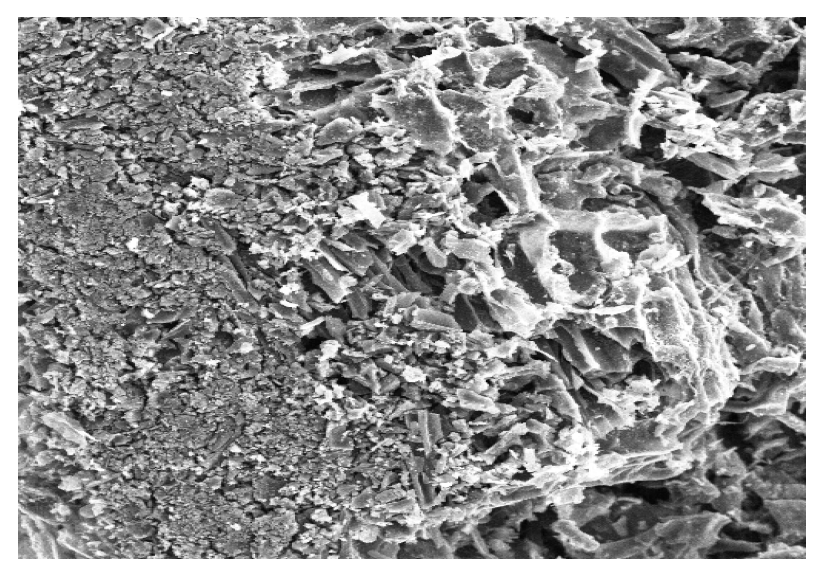

(b)

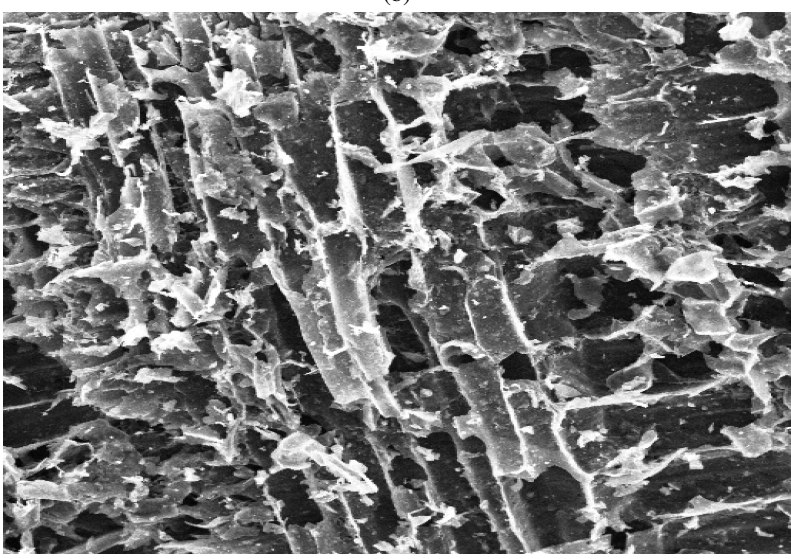

(d)

Figure 2: (a) PACB (before adsorption); (b) PACB (after adsorption); (c) ZAC (before adsorption); (d) ZAC (after adsorption) at magnification $\times 500$.

TMP per unit mass at $0.15 \mathrm{~g}$ each (at the point of intersection) (Figure 3b). 0.2, 0.3 and $0.4 \mathrm{~g}$ of ZAC adsorbed $68 \%, 82 \%$ and $87 \%$; and PACB adsorbed $65 \%, 76 \%$ and $75 \%$ of TMP respectively at equilibrium time. The equilibrium dose was reached at $0.3 \mathrm{~g}$ for both adsorbents. The economic dose for ZAC was 0.3 $\mathrm{g}$ while 0.2 for PACB.

\subsection{Effect of $\mathrm{pH}$ on Trimethoprim Adsorption}

The $\mathrm{pH}_{p z c}$ is the $\mathrm{pH}$ of solution at which electrical charge of a solid surface in the solution is neutral. The pKa of trimethoprim and the $\mathrm{pH}_{p z c}$ of the adsorbents are parameters whose electrical charge changes with $\mathrm{pH}$ of solution. The maximum attraction between the adsorbate and the adsorbents would take place when electrical charges on them are opposite. TMP is a basic compound with pKa 7.12. At $\mathrm{pH}$ above 7.12, TMP was neutral while at $\mathrm{pH}$ below 7.12 TMP was positively charged (the hypothesized interactions were presented in Equations 6 to 10 ). At $\mathrm{pH}$ below 7.12, the oxygen and nitrogen atoms on TMP donated lone pairs of electrons to the protons in solution and TMP became positively charged. At $\mathrm{pH}$ above 7.12, the lone pairs of electrons on TMP oxygen and nitrogen atoms repelled lone pairs of electrons on hydroxyl groups in solution and TMP remained neutral. At about $\mathrm{pH} \mathrm{7,} \mathrm{TMP} \mathrm{was} \mathrm{at} \mathrm{the}$ threshold of changing from positively charged $(+)$ to neutral (0), ZAC $\left(\mathrm{pH}_{p z c}\right.$ 7.6) positively charged (+) while the PACB
( $\mathrm{pH}_{p z c}$ 6.6) negatively charged (-). At $\mathrm{pH}$ below 6 , the adsorbents and trimethoprim were all positively charged and the repulsive effect de-enhanced adsorption. At $\mathrm{pH}$ above 8, lone pairs of electrons on neutral TMP repelled negatively charged adsorbents' surface and chemisorption was de-enhanced. The maximum interactions occurred at slightly acidic to neutral $\mathrm{pH}$ (pH 6) where electrical charges on the adsorbents and trimethoprim were opposite (Figure 3c). At pH 2.5, ZAC adsorbed $1.262 \mathrm{mg} / \mathrm{g}$ of TMP; at $\mathrm{pH} 5,1.266 \mathrm{mg} / \mathrm{g}$ and at $\mathrm{pH} 8,1.25$ $\mathrm{mg} / \mathrm{g}$. And for PACB, at $\mathrm{pH} 2.5,1.164 \mathrm{mg} / \mathrm{g}$ of TMP was adsorbed, at $\mathrm{pH} 5,1.215 \mathrm{mg} / \mathrm{g}$ and at $\mathrm{pH} 8,1.138 \mathrm{mg} / \mathrm{g}$.

$$
\begin{aligned}
\mathrm{TMP}(\mathrm{pKa}) & \stackrel{\mathrm{pH}>7.12}{\longrightarrow} \mathrm{TMP}(\mathrm{O}) \\
M e \mathrm{O} & \equiv N^{:}(T M P)+O H^{-} \rightarrow \text { MeÖ } \\
& \equiv N^{:}(T M P) \leftrightarrow O H^{-} \quad(\text { neutralT MP }) \\
\mathrm{TMP}(\mathrm{pKa}) & \stackrel{\mathrm{pH}<7.12}{\longrightarrow} \mathrm{TMP}(+) \\
\mathrm{MeO} & \equiv \mathrm{N}^{:}(\mathrm{TMP})+2 \mathrm{H}^{+} \rightarrow \mathrm{MeOH}^{+} \\
& \equiv \mathrm{NH}^{+}(\text {positively charged TMP })
\end{aligned}
$$

\subsection{Effect of Temperature on Trimethoprim Adsorption}

TMP is a biphenyl compound with functional group branches. The bulky structure of TMP may constitute stearic hindrance to 348 
pore accessibility. At elevated temperatures, TMP molecules acquired more kinetic energy which led to frequent knocking with the adsorbents' pore openings. The impact of the knocking might 'mend and tend' the molecules or wear the pore openings and eventually forced the molecules into the pores. The higher the temperature, the higher was the kinetic energy and the contact between molecules and pores. At equilibrium, 1.6 $\mathrm{mg} / \mathrm{g}(64 \%)$ and $1.904 \mathrm{mg} / \mathrm{g}(76 \%)$ of TMP were adsorbed by ZAC at $29^{\circ} \mathrm{C}$ (room temperature) and $60{ }^{\circ} \mathrm{C}$ respectively. Also $1.196 \mathrm{mg} / \mathrm{g}(72 \%)$ and $1.326 \mathrm{mg} / \mathrm{g}(80 \%)$ adsorbed respectively at $29^{\circ} \mathrm{C}$ and $60{ }^{\circ} \mathrm{C}$ by the PACB (Figure 3d). The enhanced adsorption of TMP on ZAC and PACB as a result of increase in temperature was economically unfavourable. From economic perspective, room temperature would be chosen considering costs of heating and cooling the system after adsorption before discharge, or environmental impact of discharged warm/hot wastewater. It would be less expensive to subject the TMP treated water to secondary adsorption process.

\subsection{Effect of initial TMP Concentrations}

The $q_{e}(\mathrm{mg} / \mathrm{g})$ of the adsorption of TMP onto ZAC and PACB increased as the initial TMP concentrations increased. This was due to the more TMP molecules in the solutions which were in contact with constant active adsorption sites on the adsorbents. For the TMP-ZAC system, at 15, 20, 25, 30, 35, 40 and $50 \mathrm{mg} / \mathrm{L}, 82.6 \%, 83.5 \%, 82.8 \%, 81 \%, 79.5 \% 75 \%$ and $70 \%$ of TMP were adsorbed respectively. And for the TMPPACB system, at $15,20,25,30,35,40$ and $50 \mathrm{mg} / \mathrm{L}, 75 \%$, $77.9 \%, 81.7 \%, 79.9 \%, 78.8 \%, 80 \%$ and $75 \%$ were adsorbed respectively (Figure 3e). A unit mass of ZAC had highest removal efficiency for TMP at $20 \mathrm{mg} / \mathrm{L}$ of solution while PACB at $25 \mathrm{mg} / \mathrm{L}$ of solution.

\subsection{Adsorption Isotherms for TMP Adsorption}

The isotherms applied to describe the adsorption of TMP onto ZAC and PACB were Langmuir, Freudlich, Temkin, RedlichPeterson, Dubinin-Radushkevich, Harkin-Jura and Halsey. The isotherms that best fit were Langmuir $\left(\mathrm{R}^{2}=0.993\right)$ and Temkin $\left(\mathrm{R}^{2}=0.962\right)$ for TMP-ZAC adsorption and TMP-PACB respectively (Table 4). These suggested that TMP-ZAC adsorption system was monolayer and TMP-PACB multilayer. The Langmuir isotherm equilibrium parameter, $R_{L}$ values: 0.108 and 0.206 for the TMP-ZAC and the TMP-PACB meant that both processes were favorable. The adsorption affinity $\left(\mathrm{K}_{L}\right)$ for ZACTMP process was higher, which implied that it was more favorable compare to PACB-TMP process. The $\mathrm{q}_{\max }$ for ZAC was $4.115 \mathrm{mg} / \mathrm{g}$ and PACB $6.495 \mathrm{mg} / \mathrm{g}$ (Table 6). The multilayer coverage exhibited by the TMP-PACB process explained its higher $\mathrm{q}_{\max }$. Also wider pores exhibited by PACB (Figure 2) might be more accessible to TMP molecules than for ZAC. Comparison of qmax of some adsorbents reported in literatures indicated that $\mathrm{ZAC}$ and $\mathrm{PACB}$ were better adsorbents for TMP adsorption from aqueous solution. The $1 / \mathrm{n}$ as determined from the Freundlich Isotherm for the TMP-ZAC and the TMP-PACB processes were $0.472 \mathrm{~g} / \mathrm{L}$ and $0.636 \mathrm{~g} / \mathrm{L}$ respectively. These further confirmed the processes to be favorable. Both processes were physical because $\mathrm{n}$ greater than 1 for
Table 4: Isotherm parameters for TMP adsorption onto the ZAC and the PACB

\begin{tabular}{|c|c|c|}
\hline Isotherm & ZAC & PACB \\
\hline \multicolumn{3}{|l|}{ Langmuir } \\
\hline $\mathrm{q}_{0}(\mathrm{mg} / \mathrm{g})$ & 4.115 & 6.495 \\
\hline $\mathrm{k}_{L}(\mathrm{~L} / \mathrm{mg})$ & 0.165 & 0.077 \\
\hline $\mathrm{R}_{L}$ & 0.108 & 0.206 \\
\hline $\mathrm{R}^{2}$ & 0.993 & 0.913 \\
\hline \multicolumn{3}{|l|}{ Freundlich } \\
\hline $\mathrm{K}_{F}(\mathrm{mg} / \mathrm{g})$ & 0.849 & 0.653 \\
\hline $\mathrm{n}(\mathrm{L} / \mathrm{g})$ & 2.120 & 1.572 \\
\hline $1 / \mathrm{n}$ & 0.472 & 0.636 \\
\hline $\mathrm{R}^{2}$ & 0.959 & 0.955 \\
\hline \multicolumn{3}{|l|}{ Temkin } \\
\hline $\mathrm{K}_{T}(\mathrm{mg} / \mathrm{L})$ & 1.306 & 1.673 \\
\hline $\mathrm{b}_{T}(\mathrm{KJ} / \mathrm{mol} / \mathrm{g} . \mathrm{L})$ & 2.531 & 0.664 \\
\hline$\beta(\mathrm{L} / \mathrm{g})$ & 0.992 & 1.500 \\
\hline $\mathrm{R}^{2}$ & 0.988 & 0.962 \\
\hline \multicolumn{3}{|l|}{ Redlich-Peterson } \\
\hline $\mathrm{K}_{R}(\mathrm{~g} / \mathrm{L})$ & 1.178 & 1.528 \\
\hline$\beta_{R}(\mathrm{~g} / \mathrm{mg} . \mathrm{K})$ & 0.0017 & 0.0013 \\
\hline $\mathrm{R}^{2}$ & 0.966 & 0.879 \\
\hline \multicolumn{3}{|c|}{ Dubinin-Radushkevich } \\
\hline $\mathrm{q}_{s}(\mathrm{mg} / \mathrm{g})$ & 2.821 & 3.320 \\
\hline $\mathrm{K}_{a d}(\mathrm{JL} / \mathrm{mol} . \mathrm{mg})$ & $2 \times 10^{-6}$ & $1 \times 10^{-8}$ \\
\hline E (KJL/mol.mg) & 0.50 & 2.5 \\
\hline $\mathrm{R}^{2}$ & 0.966 & 0.921 \\
\hline \multicolumn{3}{|l|}{ Harkin-Jura } \\
\hline $\mathrm{q}_{e}(\mathrm{mg} / \mathrm{g})$ & 1.287 & 1.220 \\
\hline $\mathrm{A}\left(\mathrm{mg}^{3} / \mathrm{g}^{3}\right)$ & 1.783 & 1.745 \\
\hline $\mathrm{R}^{2}$ & 0.840 & 0.908 \\
\hline \multicolumn{3}{|l|}{ Halsey } \\
\hline$n(g / L)$ & -2.105 & -1.572 \\
\hline $\mathrm{K}(\mathrm{mg} / \mathrm{L})$ & 1.415 & 0.668 \\
\hline $\mathrm{R}^{2}$ & 0.959 & 0.957 \\
\hline
\end{tabular}




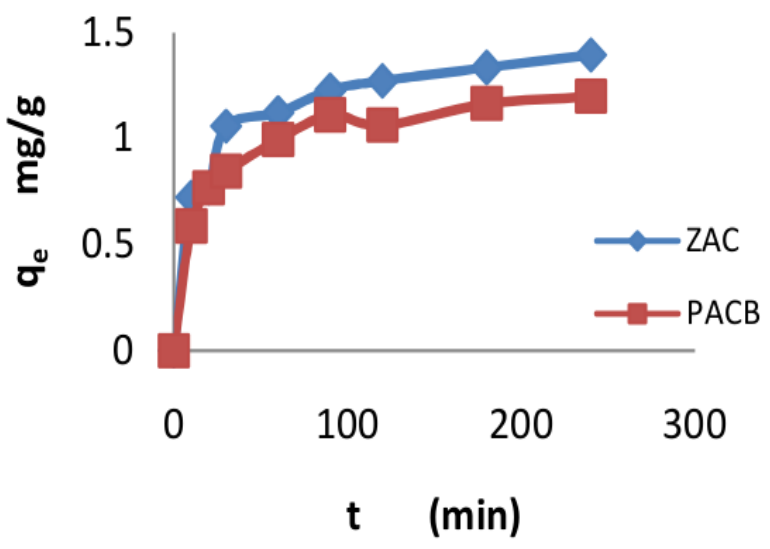

(a)

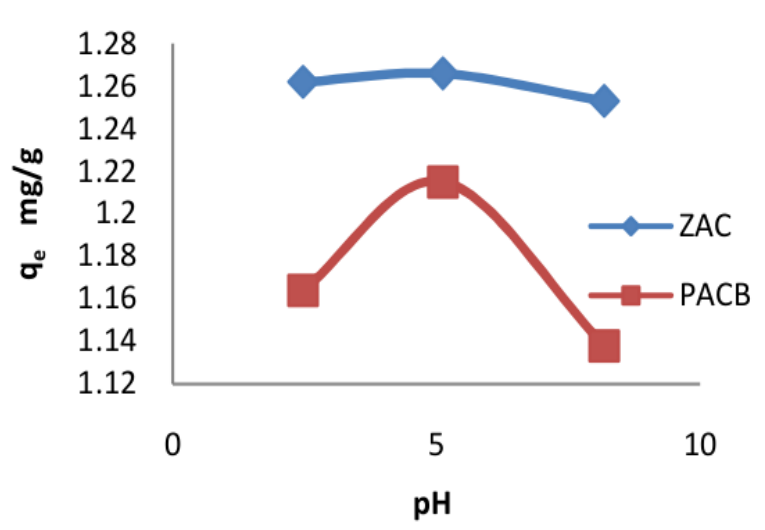

(c)

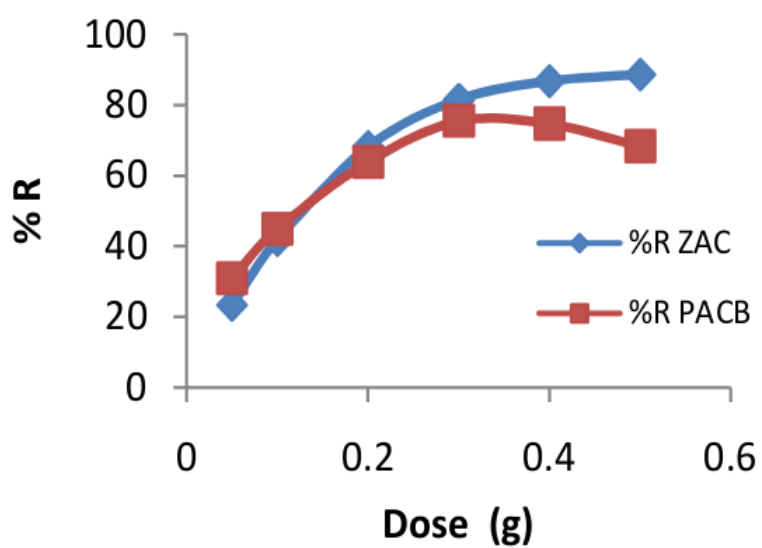

(b)

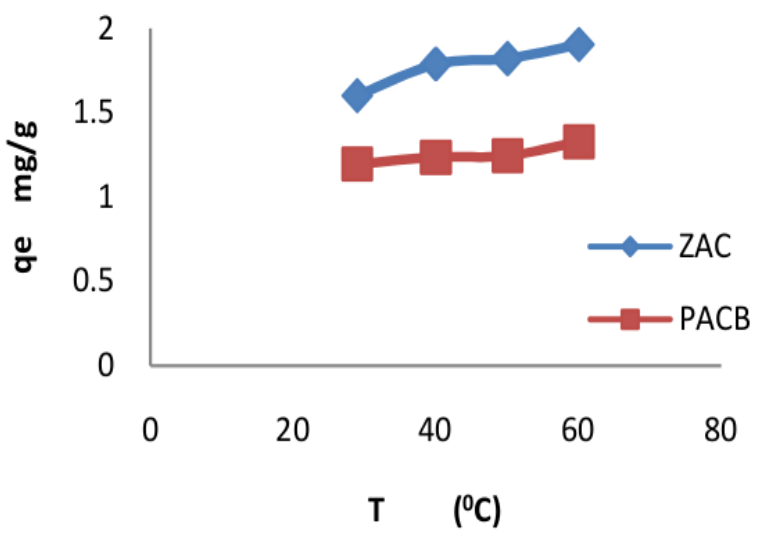

(d)

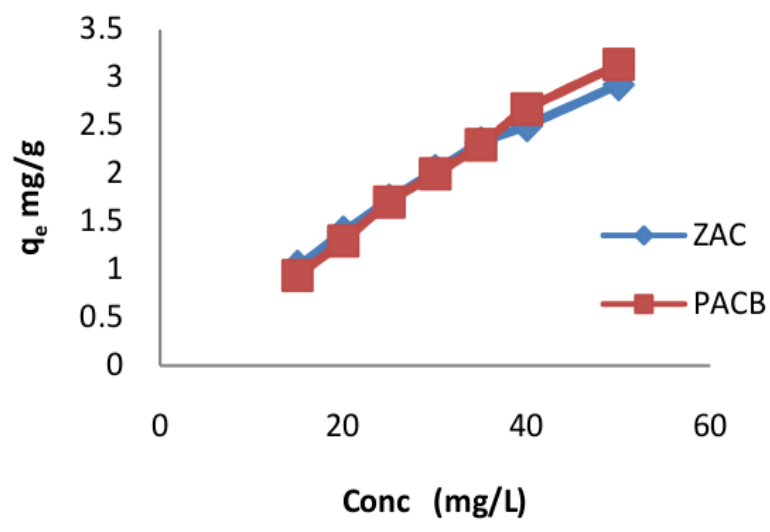

(e)

Figure 3: Effect of (a) contact time, (b) adsorbent dose, (c) solution pH, (d) temperature and (e) initial adsorbate concentration on the adsorption of TMP onto ZAC and PACB

each (Table 4). Adsorption intensity (n) was higher for ZACTMP process which in agreement with explanation given under Langmuir isotherm. 1/n, a function of surface heterogeneity, was higher for PACB-TMP system. Positive values of bonding energy $\left(b_{T}\right)$ obtained from Temkin isotherm for both processes indicated endothermic processes. The adsorption energy, $\mathrm{E}(\mathrm{kJ} / \mathrm{mol})$, derived from Dubinin-Radushkevich isotherm for the TMP-ZAC and the TMP-PACB processes were 0.50 and 2.5 respectively. These values described both processes as physical. Halsey isotherm described a heterogeneous adsorbent surface and multilayer adsorption system. Relatively close values of adsorption coefficients of both Halsey and Temkin isotherms further established PACB-TMP system as multilayer adsorption and PACB had heterogeneous surface.As could be deduced from the coefficient values of the isotherm and kinetic (section 3.9 below) models, the adsorption of TMP by ZAC and PACB involved both chemisorption and physisorption. Chemisorption involves reaction among functional groups on both the adsorbents (ZAC and PACB) and the adsorbates (TMP). Hydroxyl group would like form hydrogen bond with adsorbents' $\mathrm{N}$ and 
a

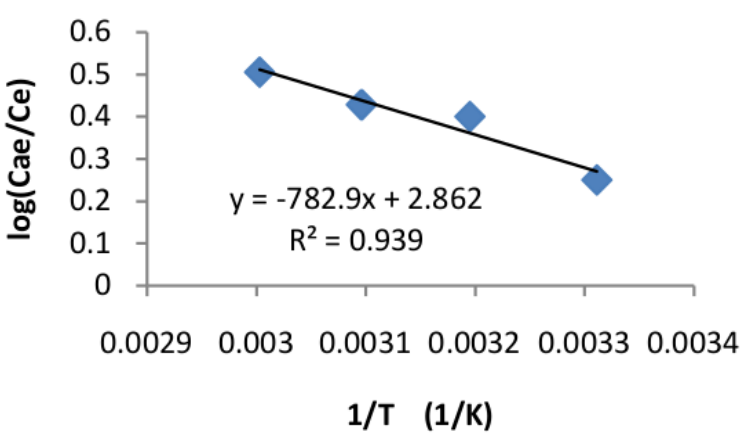

(a)

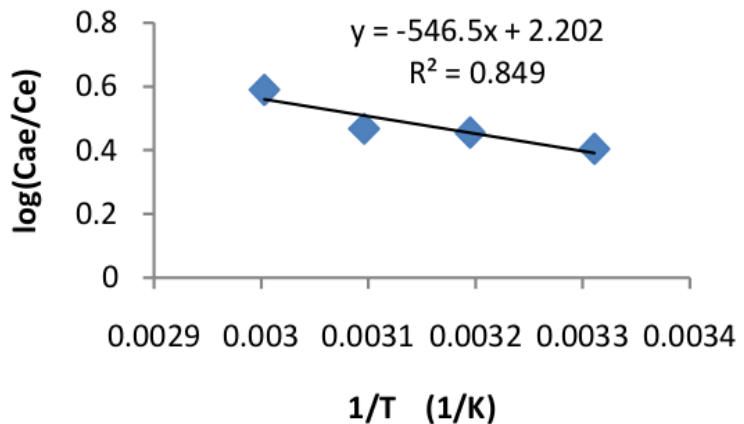

(b)

Figure 4: van't Hoff plot of $\log K$ vs $1 / T$ adsorption of TMP onto (a) ZAC and (b) PACB .

Table 5: Kinetic parameters for TMP adsorption onto the ZAC and the PACB

\begin{tabular}{lll}
\hline Kinetic & ZAC & PACB \\
\hline $\mathrm{q}_{e}$ exp $(\mathrm{mg} / \mathrm{g})$ & 1.395 & 1.200 \\
Pseudo-first order & & \\
\hline $\mathrm{q}_{e}(\mathrm{mg} / \mathrm{g})$ & 0.670 & 0.581 \\
$\mathrm{~K} 1\left(\mathrm{~min}^{-1}\right)$ & 0.014 & 0.014 \\
$\mathrm{R}^{2}$ & 0.964 & 0.920 \\
Pseudo-second order & & \\
$\mathrm{q}_{e}(\mathrm{mg} / \mathrm{g})$ & 1.425 & 1.230 \\
$\mathrm{~h}\left(\mathrm{~min}^{-1}\right)$ & 0.107 & 0.097 \\
$\mathrm{~K} 2$ & 0.053 & 0.064 \\
$\mathrm{R}^{2}$ & 0.997 & 0.997 \\
Elovich & & \\
$\mathrm{A}$ & 0.535 & 0.445 \\
$\beta(\mathrm{min} . \mathrm{g} / \mathrm{mg})$ & 4.40 & 5.05 \\
$\mathrm{R}^{2}$ & 0.939 & 0.969 \\
Intraparticle diffusion & & \\
$\mathrm{X}(\mathrm{mg} / \mathrm{g})$ & 0.594 & 0.518 \\
$\mathrm{~K}_{i d}\left(\mathrm{mg} / \mathrm{g} \cdot \mathrm{min}{ }^{1 / 2}\right)$ & 0.061 & 0.053 \\
$\mathrm{R}^{2}$ & 0.877 & 0.888 \\
$\mathrm{~B}^{2}$ & & \\
$\mathrm{X}$ & 1.475 & 1.617 \\
$\mathrm{~B}$ (min.g/mg) & -0.004 & 0.003 \\
$\mathrm{R}^{2}$ & 0.211 & 0.017 \\
\hline
\end{tabular}

Table 6: Comparison of maximum monolayer adsorption capacities of different adsorbents for TMP

\begin{tabular}{lll}
\hline Adsorbent & $\begin{array}{l}\text { Adsorbent capacity } \\
(\mathrm{mg} / \mathrm{g})\end{array}$ & Reference \\
\hline GAC & 0.51 & {$[47]$} \\
\hline PAC & 0.51 & {$[47]$} \\
Clay & 47 & {$[48]$} \\
BHB & 0.508 & {$[49]$} \\
LZB & 0.294 & {$[49]$} \\
ZAC & 4.115 & This work \\
PACB & 6.495 & This work \\
\hline GAC - granular activated carbon \\
\multicolumn{3}{l}{ PAC - powdered activated carbon } \\
sediment BHB; sediment LZB
\end{tabular}

$\mathrm{O}$ bearing functional groups, and vice versa:

$$
\begin{aligned}
\mathrm{NH}_{2} & -\mathrm{TMP}-\mathrm{NH}_{2}+\mathrm{HO}-\mathrm{ZAC} / \mathrm{PACB} \rightarrow \mathrm{H}_{2} \mathrm{~N}-\mathrm{TMP} \\
& -H N \cdots \mathrm{HO}-\mathrm{ZAC} / \mathrm{PACB}
\end{aligned}
$$

Multilayer adsorption of TMP onto PACB was as a result of reaction between electron withdrawing and electron donating functional groups on already adsorbed TMP and free adsorbate molecules in solution:

$$
\begin{aligned}
\mathrm{H}_{2} \mathrm{~N} & -T M P-H N \cdots \mathrm{HO}-\mathrm{PACB}+\mathrm{H}_{2} \mathrm{~N}-\mathrm{TMP} \rightarrow \\
& \rightarrow \mathrm{TMP}-\mathrm{H}_{2} \mathrm{~N} \cdots \mathrm{H}_{2} \mathrm{~N}-\mathrm{TMP}-\mathrm{H}_{2} \mathrm{~N} \cdots \mathrm{OH}-\mathrm{PACB}
\end{aligned}
$$

$\pi-\pi$ and $n-\pi$ are electron density centers capable of facilitating electrostatic interactions between TMP molecules and the adsorbents through resonance of conjugated double bonds and aromaticity of benzene rings:

$$
\begin{gathered}
\mathrm{TMP}-\mathrm{N}^{-}-\mathrm{C}=\mathrm{N}^{+} \mathrm{H}_{2}+\mathrm{O}^{-} \mathrm{C}_{6} \mathrm{H}_{6}-\mathrm{PACB} / \mathrm{ZAC} \rightarrow \\
\mathrm{TMP}-\mathrm{N}^{+} \ldots \mathrm{O}^{-} \mathrm{C}_{6} \mathrm{H}_{6}-\mathrm{PACB} / \mathrm{ZAC}
\end{gathered}
$$

\subsection{Kinetic Studies of Adsorption of TMP onto ZAC and PACB}

The data of adsorption of TMP on ZAC and PACB were tested with0 five different kinetic models: Pseudo-first order, 


\begin{tabular}{|c|c|c|c|c|c|c|}
\hline & \multicolumn{4}{|c|}{$\Delta \mathrm{G}^{0}(\mathrm{~kJ} / \mathrm{mol} / \mathrm{K})$} & \multirow[t]{2}{*}{$\Delta \mathrm{S}^{0}(\mathrm{~J} / \mathrm{mol} / \mathrm{K})$} & \multirow[t]{2}{*}{$\Delta \mathrm{H}^{0}(\mathrm{~kJ} / \mathrm{mol} / \mathrm{K})$} \\
\hline & 302 & 313 & 323 & 333 & & \\
\hline ZAC & -1.444 & -2.39 & -2.64 & -3.22 & +54.60 & +14.99 \\
\hline PACB & -2.342 & -2.74 & -2.90 & -3.76 & +42.16 & +10.46 \\
\hline
\end{tabular}

Pseudo-second order, Elovich, Intraparticle and Boyd. Both TMP-ZAC and the TMP-PACB processes data fitted pseudosecond order equation with $\mathrm{R}^{2}=0.997$ (Table 5). The rate of adsorption in both processes depended on the states of both the adsorbate and the adsorbents. The initial rate constants for $\mathrm{ZAC}$ and PACB, $\mathrm{h}(\mathrm{mg} / \mathrm{g} / \mathrm{min})$, were 0.107 and $0.097 \mathrm{respec}-$ tively, implied that rate at which TMP adsorbed on to the ZAC was higher initially. However, overall rate constant of PACBTMP process was higher. High adsorption coefficient $\left(\mathrm{R}^{2}\right)$ for Elovich model suggested a level of chemisorptions for both systems. Higher Elovich $\mathrm{R}^{2}$ for PACB-TMP process also indicated considerable multilayer coverage compare to ZAC-TMP process. However, earlier it was explained from the isotherm data fitting that adsorption of TMP by the adsorbents were both chemisorptions and physisorption. High coefficient values for pseudo first order kinetic and relatively high $\mathrm{R}^{2}$ for intraparticle diffusion model were pointers to physical adsorption. Surface and pore diffusions played important role in the adsorption of TMP by ZAC and PACB. PACB having wider average pore diameter than ZAC could easily accommodate bulky TMP molecules and hence higher $\mathrm{q}_{\max }$. Diffusion of TMP molecules at the surface of the adsorbents occurred rapidly while diffusion down the adsorbents' pores took place steadily until equilibrium is attained.

\subsection{Thermodynamic Study of the TMP Adsorption}

The functions of temperature, the standard enthalpy $\left(\Delta \mathrm{H}^{0}\right)$, the standard entropy $\left(\Delta S^{0}\right)$ and the standard Gibb's free energy $\left(\Delta \mathrm{G}^{0}\right)$ of the adsorption processes were investigated for spontaneity and feasibility. The van't Hoff plot of graph of log K versus $1 / T$ gave the slope and the intercept as $\Delta \mathrm{H}^{0}$ and $\Delta \mathrm{S}^{0}$ respectively (Table 7, Figure 4). The negative values for $\Delta \mathrm{G}^{0}$ at all investigated temperatures indicated that the adsorption of TMP onto ZAC and PACB were spontaneous. The positive value of $\Delta S^{0}$ showed high degree of randomness of the processes while positive value of $\Delta \mathrm{H}^{0}$ indicated endothermic processes.

\section{Conclusion}

This study verified the prospects of the processed Daniellaoliveri sawdust as adsorbents for adsorption of TMP from aqueous solution. The economic time of adsorption of TMP by both adsorbents was 60 minutes while economic doses of adsorbents were 0.3 and $0.2 \mathrm{~g}$ for ZAC and PACB respectively at $29{ }^{\circ} \mathrm{C}$. The $q_{\max }$ of both the ZAC and the PACB was obtained at slightly acidic-neutral $\mathrm{pH}$. The ZAC data fitted best into the Langmuir isotherm and the PACB, the Temkin while data for both fitted best the pseudo-second order kinetic. Multilayer adsorption and average pore diameter were suspected to be responsible for higher $q_{\max }$ in PACB. The $\Delta \mathrm{G}^{0}$ values indicated that the adsorption processes were spontaneous and feasible. Also both reactions were endothermic and physical. The study revealed that Daniellia—oliveri sawdust based activated carbons were promising adsorbents for removal of TMP from water.

\section{Acknowledgements}

This research did not receive any specific grant from funding agencies in the public, commercial, or not-for-profit sectors.

\section{References}

[1] S. Hong, C. Ning, L. Jianguang, W. Dawei \& X. Weixue "Preparation of Clay Nanocomposites Matrix", Journal of Chemical Science and Technology 2 (2013) 128.

[2] Q. Sui, X. Cao, S. Lu, W. Zhao, Z. Qiu \& G. Yu "Occurrence, sources and fate of pharmaceuticals and personal care products in the groundwater: A review", Emerging Contaminants 1 (2015) 14, https://doi.org/10.1016/j.emcon.2015.07.001.

[3] Y. Luo, W. Guo, H. H. Ngo, L. D. Nghiem, F .I. Hai, J. Zhang \& X. C. Wang "A review on the occurrence of micropollutants in the aquatic environment and their fate and removal during wastewater treatment", Science of the Total Environment 473 (2014) 619, https://doi.org/10.1016/j.scitotenv.2013.12.065.

[4] D. C. Bean, D. M. Livermore, I. Papa \& L .M. Hail "Resistance among Escherichia eoli to sulphonamides and other antimicrobials now little use in man", J. Antimicrobchemother 56 (2005) 962.

[5] C. L. Ventola "The antibiotic resistance crisis: part 1: causes and threats", Pharmacy and Therapeutics 40 (2015) 277.

[6] A. J. Ebele, M. A. E. Abdallah \& S. Harrad "Pharmaceuticals and personal care products (PPCPs) in the freshwater aquatic environment", Emerging Contaminants (2017) 13, https://doi.org/10.1016/j.emcon.2016.12.004.

[7] D. Maddileti, B. Swapna \& A. Nangia "Tetramorphs of the antibiotic drug trimethoprim: characterization and stability", Cryst Growth Des $\mathbf{1 5}$ (2015) 1745, https://doi.org/10.1021/cg501772t.

[8] F .J. Peng, G. G. Ying, Y. S. Liu, H. C. Su \& L. Y. He "Joint antibacterial activity of soil-adsorbed antibiotics trimethoprim and sulfamethazine", Sci Total Environ 506 (2015) 58, DOI:10.1016/j.scitotenv.2014.10.117.

[9] T. Thomas "Sulfamethoxazole/Trimethoprim ratio as a new marker in the raw wastewaters: a critical review", Science of the total Environment (2020), doi: 10.1016/j.scitotenv.2020.136916.

[10] P. P. Gao, D. Q. Mao, Y. Luo, L. M. Wang, B. J. Xu \& L. Xu "Occurrence of sulfonamide and tetracycline-resistant bacteria and resistance genes in aquaculture environment", Water Res 46 (2012) 2355, DOI: 10.1016/j.watres.2012.02.004.

[11] E. Pradhan, S. Bhandari \& R.E. Gilbert "Antibiotics versus no treatment for toxoplasma retinochoroiditis", Cochrane Database Syst Rev 5 (2016), doi: 10.1002/14651858.CD002218.pub2.

[12] O. S. Jurg "An environmental risk assessment for human-use trimethoprim in European surface waters", Antibiotics 2 (2013) 115-162, Doi:10.3390/antibiotics2010115. 
[13] J. O. Straub "An Environmental Risk Assessment for Human-Use Trimethoprim in European Surface Waters", Antibiotics 2 (2013) 115162, doi: 10.3390/antibiotics2010115.

[14] D. Dolar, N. Drašinac, K. Košutić, I. Škorić \& D. Ašperger "Adsorption of hydrophilic and hydrophobic pharmaceuticals on RO/NF membranes: identification of interactions using FTIR", J. Appl Polym Sci 134, (2017), https://doi.org/10.1002/app.44426.

[15] E. C. Salihi \& M. Mahramanlioglu "Equilibrium and kinetic adsorption of drugs on bentonite: presence of surface active agents effect", Appl Clay Sci 101 (2014) 381, doi:10.1016/j.clay.2014.06.015.

[16] C. Avila \& J. García "Pharmaceuticals and Personal Care Products (PPCPs) in the Environment and Their Removal from Wastewater through Constructed Wetlands", Elsevier Science \& Technology 195 (2015), https://doi.org/10.1016/B978-0-444-63299-9.00006-5.

[17] Q. Liu, M. Li, F. Zhang, H. Yu, Q. Zhang \& X. Liu "The removal of trimethoprim and sulfamethoxazole by a high infiltration rate artificial composite soil treatment system", Frontiers of Environmental Science and Engineering 11, 12 (2017), https://doi.org/10.1007/s11783-0170920-z.

[18] M. Samuel, M. Rosa, G. Jairo, S. Joanna, G. Sebastiano, R.C. Juan \& P.O. Maria "Towards the removal of antibiotics detected in wastewaters in the POCTEFA territory: occurrence and $\mathrm{TiO}_{2}$ photocatalytic pilot-scale plant performance", Water, 12 (2020) 1453, doi: 10.3390/w12051453.

[19] J. T. Wang, J. Hu \& S. W. Zhang "Studies on the sorption of tetracycline onto clays and marine sediment from seawater", J. Colloid Interface Sci 349 (2010) 578, https://doi.org/10.1016/j.jcis.2010.04.081.

[20] Y. L. Zhang, S. S. Lin, C. M. Dai, L. Shi \& X .F. Zhou "Sorptiondesorption and transport of trimethoprim and sulfonamide antibiotics in agricultural soil: effect of soil type, dissolved organic matter, and $\mathrm{pH}$ ", Environ Sci Pollut Res 21 (2014) 5827, https://doi.org/10.1007/s11356014-2493-8.

[21] J. R. Li, Y. X. Wang, X. Wang, B. L. Yuan \& M. L. Fu "Intercalation and adsorption of ciprofloxacin by layered chalcogenides and kinetics study", J. Colloid Interface Sci 453 (2015) 69, DOI: 10.1016/j.jcis.2015.03.067.

[22] H. Liu, J. Zhang, H. H. Ngo, W. Guo, H. Wu, Z. Guo, C. Cheng \& C. Zhang "Effect on physical and chemical characteristics of activated carbon on adsorption of trimethoprim: mechanisms study", RSC Adv 5 (2015) 85187, https://doi.org/10.1039/C5RA17968H.

[23] J. Li \& H. Zhang "Adsorption-desorption of oxytetracycline onmarine sediments: kinetics and influencing factors", Chemosphere 164 (2016) 156, https://doi.org/10.1016/j.chemosphere.2016.08.100.

[24] M. Pan \& L. M. Chu "Adsorption and degradation of five selected antibiotics in agricultural soil", Science of the Total Environment 545 (2016) 48, doi: 10.1016/j.scitotenv.2015.12.040.

[25] M. Ming-sheng, M. Shuai-shuai, S. Li, K. Qiang \& L. Yu-zhen "Adsorption characteristics of antibiotics trimethoprim by activated carbon developed from low-cost alligator weed: kinetics, equilibrium and thermodynamic analyses", Desalination and Water Treatment, (2017) 1, doi: 10.5004/dwt.2017.21053.

[26] U. P. Onohie, E. K. Orhorhoro \& P. E. Oyiboruona "Economic Potential and Benefits of Sawdust in Nigeria", International Journal of Research Publication 9 (2018) 1.

[27] A. Reem, Al-Bayati, S. Athraa \& Ahmed "Adsorption - Desorption of Trimethoprim Antibiotic Drug from Aqueous Solution by Two Different Natural Occurring Adsorbents", International Journal of Chemistry 3 (2011), doi:10.5539/ijc.v3n3p21.

[28] PubChem Trimethiprim. National Center for Biotechnology Information.
U.S. National Library of Medicine

[29] A. A. Giwa, S. A. Adesokan \& I. A. Bello "Adsorption of pyrimethamine from wastewater using activated carbons prepared from Daniellia-oliveri sawdust", Inter. J. Env. Anal. Chem 1, (2021), DOI: $10.1080 / 03067319.2021 .1884858$.

[30] R. Malik, D. S. Ramteke \& S. R. Wate "Physico-Chemical and Surface Characterization of Adsorbent Prepared From Groundnut Shell by $\mathrm{ZnCl}_{2}$ Activation and its Ability to Adsorb Colour", India journal of chemical technology (2006) 319.

[31] R. M. Shrestha, A. P. Yadav, B. P. Pokharel \& R. R. Pradhananga "Preparation and Characterization of Activated Carbon from Lapsi (Choerospondias axillaris) Seed Stone by Chemical Activation with Phosphoric acid", Res. J. Chem. Sci 2 (2012) 10.

[32] G. Halsey "Physical Adsorption on non-uniform surfaces", J. Chem. Phys 16 (1948) 931-937.

[33] W. D. Harkins \& W. D. Jura "Adsorption equation", J. Chem, Phys 11 (1943) 430.

[34] I. Langmuir "The adsorption of gases on plane surfaces of glass, mica and platinum”, J. Am. Chem. Soc 40 (1918) 1361.

[35] H. M. F. Freundlich "Over the Adsorption in Solution", J. Phys. Chem 57 (1906) 385.

[36] M. I. Tempkin \& V. Pyzhev "Kinetics of Ammonia Synthesis on Promoted Iron Catalyst", Acta Phys. Chim. USSR 12 (1940) 327.

[37] C. H. Giles, D. Smith \& A. A. Huitson "A general treatment and classification of the solute adsorption isotherm", Theoretical, J. Colloid Interface Sci 47 (1974) 755.

[38] W. Rieman \& H. Walton "International series of monographs in analytical chemistry, 38: Ion exchange in analytical chemistry", Oxford: Pergamon Press (1970).

[39] W.T. Weber \& K.P. Chakraborty "Pore and solid diffusion model for fixed bed adsorbent", J. Am. Inst. Chem. Eng 20 (1974) 228.

[40] F. Helfferich "Ion exchange" New York: McGraw-Hill Book Co (1962).

[41] S. Lagergren "Zur theorie der sogenannten adsorption gelöster stoffe", Kungliga Svenska Vetenskapsakademiens. Handlingar Band 24 (1898) 1.

[42] Y. S. Ho \& G. McKay, Can J Chem Eng 76 (1998) 822.

[43] D. L. Sparks "Kinetics of Reactions in Pure and Mixed Systems in Soil Physical Chemistry", CRC Press, Florida (1986) 21.

[44] F. E. Okiemen \& V. U. Onyega "Binding of Cadmium, Copper, Lead and Nickel Ions with Melon (Citrullus vulgaris) Seed Husk", Biological waste 29 (1989) 11.

[45] J. W. Weber \& C. J. Morris "Proceedings of the International Conference on Water Pollution Symposium", Pergamon Press, Oxford 2 (1962) 231266.

[46] G. Boyd, A. Adamson \& L. Myers "The exchange adsorption of ions from aqueous solutions by organic zeolites. II kinetics", J Ame. Chem. Soc 69 (1974) 2836.

[47] A. O. Michael, O. M. Vincent, O. W. Shem, M. N. Holiness, W. M. Charles \& U. Mamo "Adsorption Studies of Trimethoprim Antibiotic on Powdered and Granular Activated Carbon in Distilled and Natural Water", Int. J. S. Res. Sci. Engg. Technol 4 (2018) 223, DOI : https://doi.org/10.32628/IJSRSET1841117.

[48] A. H. Al-Shukrawi, Y .A. Al-Baitai \& H. D. Fadhel "Characteristics of Trimethoprim Adsorption on Attapulgite Iraqi Clay", J Chem Eng Process Technol 8 (2017), DOI: 10.4172/2157-7048.1000365.

[49] L. Jia \& Z. Hua "Factors influencing adsorption and desorption of trimethoprim on marine sediments: mechanisms and kinetics", Environ Sci Pollut Res 24 (2017) 21929. DOI 10.1007/s11356-017-9693-y. 